\title{
Treatment of intestinal helminthiasis: mebendazole only or mebendazole-pyrantel pamoate?
}

\author{
Wisman Dalimunthe, Charles Siregar, Munar Lubis, Syahril Pasaribu, Chairuddin P. Lubis
}

\begin{abstract}
Background Although intestinal helminthiasis causes high morbidity and has a negative impact on children's growth and development, the efficacy of antihelmintics for multiple helminthiasis in mass treatment is still doubtful.

Objective To compare the efficacy of single dose mebendazole and a combination of pyrantel pamoate and mebendazole for the treatment of multiple infections due to Ascaris lumbricoides, hookworm, and Trichuris trichiura.

Methods Subjects were elementary school students in Suka Village, Tiga Panah subdistrict, North Sumatera. They were randomized to either receive mebendazole (M Group) or mebendazolepyrantel pamoate group (MP Group). Stool examinations were perfomed on each subjects on day 7, 14,21, and 28 after treatment. Analyses were perfomed by using chi-squared and Mann-Whitney U tests.

Results The prevalence of intestinal helminthiasis was 95.4\%. T. trichiura $(88.7 \%)$ was the most common cause of infection followed by A. lumbricoides (79.5\%), and hookworm (3.1\%). Two hundred thirty nine $(76.8 \%)$ children had multiple infections. Although the egg reduction rate of intestinal helminthiasis in the combination group was faster than that of the mebendazole group, there was no significant difference in the cure rate of both groups. Conclusion A single dose of mebendazole is preferred for mass treatment of multiple intestinal helminthiasis infections. [Paediatr Indones 2007;47:216-220].
\end{abstract}

Keywords: helminthiasis, mebendazol, pyrantel
pamoate, Ascaris lumbricoides, Trichuris trichiura,

Keywords: helminthiasis, mebendazol, pyrantel
pamoate, Ascaris lumbricoides, Trichuris trichiura, hookworm . 
Wisman Dalimunthe et al: Treatment of intestinal helminthiasis: mebendazole only or mebendazole-pyrantel pamoate?

single dose anthelmintic therapy gives satisfying result. However, treatment of other helminths such as Trichuris trichiura and hookworm often gives disappointing results.

Several anthelmintics in varying regimens have been tried to eradicate those parasites with various results. One of the most frequently used anthelmintics is a single dose pyrantel pamoate $10 \mathrm{mg} / \mathrm{kg}$ followed by mebendazole $100 \mathrm{mg}$ twice daily for 3 consecutive days. ${ }^{5}$ This method is neither practical nor convenient especially for mass treatment. Ideally, anthelmintics should satisfy the needs of the majority of patients, including simple regimen, easy to administer, low cost, minimal side effect, high therapeutic effect, and effective to all parasite stadia. ${ }^{1,3}$ Recently, a single dose $500 \mathrm{mg}$ mebendazole is used an alternative treatment. ${ }^{6,7}$ However, study on the effectiveness of two or more anthelmintics for intestinal helminthiasis in mass treatment is still rare, especially for multiple or mixed helminthiasis. Therefore, this study aimed to investigate the effectiveness of two different antihelmintics for multiple helminthiasis infection.

\section{Methods}

This randomized double blind clinical trial was conducted in primary schools from September to October 2002, in Suka village Tiga Panah subdistrict, Karo district, North Sumatera. Stool of all students (grades I to VI) was collected in plastic bottles. Stool was then examined using Kato-Katz technique in the Department of Child Health, Medical School, North Sumatra University.

We included all students of the primary schools who had more than one species of intestinal helminths in their stools, but had not taken anthelmintic for one month prior to the study. They must be otherwise healthy on doctor's examination and gave parental consent. Participants were then randomized to either receive oral single dose pyrantel pamoate 10 $\mathrm{mg} / \mathrm{kg}$ followed by mebendazole $100 \mathrm{mg}$ twice daily for 3 consecutive days (PM Group), or single dose mebendazole $500 \mathrm{mg}$ only (M Group). Using the same method, stool examinations were repeated on $7^{\text {th }}, 14^{\text {th }}$, $21^{\text {st }}$, and $28^{\text {th }}$ day after treatment to determine egg reduction rate and cure rate. A complete cure was defined as no egg detected on a single Kato-Katz smear technique one to four weeks after treatment. Side effects of the anthelmintics were observed and recorded.

Data of students who could not complete the study, those who failed to consume the antihelmintic regularly, and those who had severe side effects of the anthelmintics were excluded from analysis. We used chi-squared test to compare the effectiveness of treatment between the two groups. To asses the eggs reduction rate we used Mann-Whitney U test. All data were processed by SPSS version 11.0 for windows.

\section{Results}

Stool specimens were initially examined from a total of 326 subjects, 311 (95.4\%) were found to be positive for helminth infection. Trichuriasis had the highest prevalence $(88.7 \%)$, followed by ascariasis $(79.5 \%)$, and hook worm infection (3.1\%). Seventy-two $(23.2 \%)$ of the test specimen had single and 239 (79.8\%) had multiple infection (Table 1).

Of 239 students with multiple helminthiasis, 140 specimens were randomly taken and randomized into PM or M grop, so there were 70 students in each group. At the end of the study, there was 1 student in PM group and 5 students in $\mathrm{M}$ group who could not finish the study because of sick, moved to another school, or no stools obtained at examination time. The characteristics of the subjects in both groups are shown in Table 2; both groups were essentially comparable.

Egg reduction rate of helminths in both PM and $\mathrm{M}$ group are shown in Table 3. On day 7 after treatment, there was a significant difference of egg reduction rate of Trichuris $92.6 \%$ in the PM group, and

Table 1. Prevalence and variation of intestinal helminth in 326 subjects

\begin{tabular}{lcc}
\hline Intestinal helminth infections & Total & $\%$ \\
\hline Type of infection: & & \\
A. lumbricoides & 259 & 79.5 \\
T. trichiura & 289 & 88.7 \\
$\quad$ Hookworm & 10 & 3.1 \\
Single infection: & & \\
A. lumbricoides & 21 & 6.5 \\
T. trichiura & 51 & 15.6 \\
Multiple infection: & & \\
A.lumbricoides + T.trichiura & 229 & 70.2 \\
A.lumbricoides + Hookworm & 1 & 0.3 \\
T.trichiura + Hookworm & 1 & 0.3 \\
A.lumbricoides + T.trichiura + Hookworm & 8 & 2.5 \\
\hline
\end{tabular}

Paediatr Indones, Vol. 47, No. 5, September 2007 • 217 
Wisman Dalimunthe et al: Treatment of intestinal helminthiasis: mebendazole only or mebendazole-pyrantel pamoate?

Table 2. Baseline characteristics of PM Group and M Group

\begin{tabular}{lcc}
\hline Characteristic & \multicolumn{2}{c}{$\begin{array}{c}\text { Combination Mebendazole } \\
\text { Group }\end{array}$} \\
\hline S e x & & \\
Boy & 40 & 28 \\
Girl & 29 & 37 \\
Body weight, kg, mean (SD) & $27.2(6.41)$ & $27.8(6.53)$ \\
Age, yr, mean (SD) & $10.6(1.76)$ & $10.5(1.89)$ \\
\hline
\end{tabular}

79.3\% in $\mathrm{M}$ group $(\mathrm{P}=0.042)$, but there were no significant difference in eggs reduction rate of Ascaris. On day 14, 21, and 28 after treatment, there were no significant difference in egg reduction rate of Trichuris and Ascaris in both PM and M group.

The cure rate of helminths in both PM and M groups are shown in Table 4. On day 7 after treatment, there was a significant difference of the cure rate of Ascaris and Trichuris in both PM and M groups. The cure rate of Ascaris in the PM group was $92.8 \%$ and in $\mathrm{M}$ group was $76.9 \%(\mathrm{P}=0.01)$. The cure rate of Trichuris in $\mathrm{PM}$ group was $88.4 \%$ and in $\mathrm{M}$ group was $73.6 \%(\mathrm{P}=0.03)$. On the $14^{\text {th }}, 21^{\text {st }}$, and $28^{\text {th }}$ day after treatment, no significant difference of the cure rate of Trichuris and Ascaris was found in both PM and M group. The prevalence of hookworm infection was only $3.1 \%$ and not considered for further analysis.

\section{Discussion}

The prevalence of intestinal helminthiasis in this study was similar to that of previous studies. Study of 348 elementary school students in Jakarta reported that prevalences of A. lumbricoides, T. trichiura, and hookworm were $85.1 \%, 92 \%$, and $2.1 \%$, respectively. ${ }^{7}$ Similar results were reported by other studies in

Table 3. Mean of egg reduction rate (ERR) from the $1^{\text {st }}$ week until $4^{\text {th }}$ week after treatment

\begin{tabular}{cccr}
\hline Week & PM $(\%)$ & $\mathrm{M}(\%)$ & $\mathrm{P}$ \\
& $\mathrm{N}=69$ & $\mathrm{~N}=65$ & \\
\hline $1^{\text {st }}: \mathrm{AL}$ & 98.4 & 98.3 & $>0.05$ \\
TT & 92.6 & 79.3 & 0.04 \\
HW & 100 & 100 & \\
$2^{\text {nd }}:$ AL & 100 & 99.9 & $>0.05$ \\
TT & 97.2 & 94.9 & \\
$3^{\text {rd }}:$ AL & 100 & 99.9 & \\
TT & 98 & 98.1 & \\
$4^{\text {th }}:$ AL & 100 & 99.9 & \\
TT & 97.9 & 98.1 & \\
\hline
\end{tabular}

Table 4. Mean of cure rate $(C R)$ from $1^{\text {st }}$ week until $4^{\text {th }}$ week after treatment

\begin{tabular}{cccc}
\hline Week & $\begin{array}{c}\text { Combination } \\
\text { group (\%) } \\
\mathrm{N}=69\end{array}$ & $\begin{array}{c}\text { Mebendazol } \\
\text { group (\%) } \\
\mathrm{N}=65\end{array}$ & $\mathrm{P}$ \\
\hline $1^{\text {st }}: \mathrm{AL}$ & 92.8 & 76.9 & 0.01 \\
TT & 88.4 & 73.8 & 0.03 \\
HW & 100 & 100 & \\
$2^{\text {nd }}:$ AL & 100 & 96.9 & $>0.05$ \\
TT & 91.3 & 86.2 & \\
$3^{\text {rd }}:$ AL & 100 & 96.9 & \\
TT & 92.8 & 89.2 & \\
$4^{\text {th }}:$ AL & 100 & 96.9 & \\
TT & 94.2 & 92.3 & \\
\hline
\end{tabular}

$\mathrm{AL}=$ Ascaris lumbricoides; $\mathrm{TT}=$ Trichuris trichiura; $\mathrm{HW}=$ hookworm

Indonesia. ${ }^{2,8}$ In Malaysia, the prevalence of A.lumbricoides, T.trichiura, and hookworm were $62.9 \%$, $91.7 \%$, and $28.8 \%$ respectively. ${ }^{9}$ Merid et al ${ }^{10}$ in Ethiopia, Clewes et al ${ }^{11}$ in Bangladesh, Albonico et all ${ }^{12}$ in Zanzibar, Oyewole et $a^{13}$ in Nigeria, Watkins ${ }^{14}$ in Guatemala, and Smith et $a^{15}$ in Honduras reported similar prevalence of intestinal helminthiasis. However some studies reported lower prevalence of helminthiasis Some studies had lower prevalence of helminthiasis both in Indonesia, ${ }^{16,17}$ and in Guinea. ${ }^{18}$

High prevalence of ascariasis and trichuriasis in this study probably due to poor personal hygiene and the condition of study location is high in humidity and agriculture surrounding. On the other hand, the low prevalence of ascariasis and trichuriasis in some studies are probably caused by frequent participation of subjects. ${ }^{19}$

Not all studies reported the prevalence of multiple infections. In this study, $70.2 \%$ of children had both ascariasis and trichuriasis simultaneously. Similar results were reported by many studies. $7,8,20-23$ The reason for this is unclear, but it may be explained by the similar route of infection for the two parasites. ${ }^{15}$

In our study at the end of stool examination, the egg reduction rate (ERR) of Ascaris lumbricoides and Trichuris trichiura were $100 \%$ and $97.9 \%$ in combination group and $99.9 \%$ and $98.1 \%$ in mebendazole group. Legesse et al ${ }^{24}$ used mebendazole $2 \times 100 \mathrm{mg}$ for 3 consecutive days and obtained ERR of 99.8 and 92.3\% for A. lumbricoides and T. trichiura. Abidin and Rassad ${ }^{7}$ used single dose mebendazole $500 \mathrm{mg}$ and found that the ERR was $99.8 \%$ and $89.7 \%$ for $A$. lumbricoides and T. trichiura, respectively. Abadi ${ }^{6}$ used single dose mebendazole $500 \mathrm{mg}$ and found that ERR 
Wisman Dalimunthe et al: Treatment of intestinal helminthiasis: mebendazole only or mebendazole-pyrantel pamoate?

was $99.0 \%$ and $92.8 \%$ for A. lumbricoides and $T$. trichiura. Jongsuksuntigul et al ${ }^{25}$ also used single dose mebendazole $500 \mathrm{mg}$ and found the ERR $100 \%$ and 89.9\% for A.lumbricoides and T.trichiura.

There was significant difference in the cure rate $(\mathrm{CR})$ in the $7^{\text {th }}$ day of stool examination, in which combination was greater than mebendazole group. But at the end of the stool examination, there was no significant difference between the two groups. CR of combination group were $100 \%$ and $94.2 \%$ for A. lumbricoides and T. trichiura, respectively, while in mebendazole group were $96.9 \%$ and $92.3 \%$ for A. lumbricoides and T. trichiura, respectively. It suggests that combination of pyrantel pamoate-mebendazole eliminates intestinal helminth faster than does single dose mebendazol. The very high $\mathrm{CR}$ of ascariasis in this study was similar with other studies. ${ }^{7,26-28}$ However the CR of trichuriasis in this study was higher than that in other studies. Abidin and Rassad ${ }^{7}$ used single dose mebendazole $500 \mathrm{mg}$ in trichuriasis obtained only a $41.7 \%$ CR. Purnomo et al ${ }^{26}$ found only $12.4 \%$ CR using pyrantel pamoate, that was similar to that found Albonico et al ${ }^{12}$ using mebendazole. The high CR for trichuriasis in this study is possibly related to the fact that our subjects had never included in the trial so that compliance was better.

Some studies had reported the side effect of antihelmintic especially mebendazole. Abidin ${ }^{7}$ reported $3.8 \%$ of erratic migration of ascaris as side effect of mebendazole. ${ }^{7}$ Purnomo et al ${ }^{26}$ suggested that mebendazole was not widely used in Indonesia, mainly because it stimulates erratic migration of A. lumbricoides. The basic principle was to combine a rapid acting, worm neurotoxic agent to mebendazol in order to quickly paralyze Ascaris. Kan and Chua ${ }^{29}$ suggested that the combination of mebendazole and levamisol had decreased the possibility of erratic migration of ascaris in mixed infection. Some experts recommend to use mebendazole in mass treatment because it is given as a single dose, it has a large spectrum property, safe, and easy to administer without considering body weight. ${ }^{6,7}$ Unfortunately, mebendazole is more expensive than other antihelmintics. No side effect was found in our study.

In conclusion, treating intestinal helminthiasis by combination of single dose pyrantel pamoate $10 \mathrm{mg} / \mathrm{kg}$ body weight followed by mebendazole $2 \times 100 \mathrm{mg}$ for 3 consecutive days eliminates intestinal helminth faster compared to that by single dose $500 \mathrm{mg}$ mebendazole only. However there is no significant difference of cure rate of intestinal helminthiasis between both combination and single dose mebendazole, suggesting that a single dose of mebendazol is preferred for mass treatment of multiple helminth infections.

\section{References}

1. Crompton DWT, Montresor A, Nesheim MC, Savioli L, editors. Controlling disease due to helminth infections. Geneva: WHO; 2003.

2. Sasongko A. Duabelas tahun pelaksanaan program pemberantasan cacingan di sekolah-sekolah dasar DKI Jakarta (1987-1999). J Epidemiol Indones 2000;4:41-51.

3. Gani EH. Efek ovisidal mebendazol dan albendazol terhadap Ascaris lumbricoides dan Trichuris trichura [thesis]. Medan: Universitas Sumatera Utara; 1997.

4. Warren KS, Bundy DAP, Anderson RM. Helminth infection. In: Jamison DT, Mosley WH, Measham AR, Bobadilla JL, editors. Priorities in developing countries. New York: Oxford University Press; 1999. p. 131-60.

5. Pasaribu S. Anthelmintik generasi baru. Proceedings of the One Day Simposium "Anthelmintik generasi baru";1989 ;Medan.

6. Abadi K. Single dose mebendazole therapy for soil-transmitted nematodes. Am J Trop Med Hyg 1985;34:129-33.

7. Abidin SAN, Rassad R. Pengobatan infeksi nematoda usus dengan mebendazole $500 \mathrm{mg}$ dosis tunggal. MEDIKA 1990;3:192-7.

8. Hadju V, Abadi K, Stephenson LS, Noor NN, Mohammed $\mathrm{HO}$, Bowman DD. Intestinal helminthiasis, nutritional status, and their relationship; a cross-sectional study in urban slum school children in Indonesia. Southeast Asian J Trop Med Public Health 1995;26:719-29.

9. Norhayati M, Zainuddin B, Mohammod CG, Oothuman P, Azizi O, Fatmah MS. The prevalence of trichuris, ascaris and hookworm infection in orang asli children. Southeast Asian J Trop Med Public Health 1997;28:161-8.

10. Merid Y, Hegazy M, Mekete G, Teklemariam S. Intestinal Helminthic infection among children at Lake Awassa Area, South Ethiopia. Ethiop J Health Dev 2001;15:31-8.

11. Clewes CAN, Rousham EK, Taylor CGNM, Lunn PG. Anthelmintic treatment of rural Bangladeshi children: effect on host physiology, growth and biochemical status. Am J Clin Nutr 2001;73:53-60.

Paediatr Indones, Vol. 47, No. 5, September $2007 \bullet 219$ 
Wisman Dalimunthe et al: Treatment of intestinal helminthiasis: mebendazole only or mebendazole-pyrantel pamoate?

12. Albonico M, Stoltzfus, Savioli L, Chwaya HM, d'Harcourt

E, Tielsch JM. A controlled evaluation of two school-based anthelminthic chemotherapy regimens on intensity of intestinal helminth infections. Int J Epidemiol 1999; 28:591-6.

13. Oyewole F, Ariyo F, Sanyaolu A. Intestinal helminthiases and their control with albendazole among primary schoolchildren in riverine communities of Ondo State, Nigeria. Southeast Asian J Trop Med Public Health 2002;33:214-7.

14. Watkins WE, Pollitt E. Effect of removing Ascaris on the growth of Guatemalan schoolchildren. Pediatrics 1996; 97:871-6.

15. Smith HM, Dekaminsky RG, Niwas S, Soto RJ, Jolly PE. Prevalence and intensity of infections of Ascaris lumbricoides and Trichuris trichiura and associated socio-demographic variables in four rural Honduran communities. Mem Inst Oswaldo Cruz, Rio de Janeiro 2001;96:303-14.

16. Sutoto J, Indriono. The current prevalence rate of soil transmitted helminthiasis in Indonesia. Pediatr Indones 1992;32:304-11.

17. Sadjimin T, P Jeanne R. Hubungan antara infestasi cacing dan prestasi belajar anak sekolah dasar di Kecamatan Ampana Kota Kabupaten Poso Sulawesi Tengah. J Epidemiol Indones 2000;4:17-26.

18. Glickman LT, Camara AO, Glickman NW, McCabe GP. Nematode intestinal parasites of children in rural Guinea, Africa: prevalence and relationship to geophagia. Int J Epidemiol 1999;28:169-74.

19. Ismid IS, Subahar R, Darnely, Margono SS, Abidin SAN. Potensi transmisi Ascaris lumbricoides dan Trichuris trichiura pasca pengobatan dengan obat cacing. Maj Parasitol Ind 1997;10:66-71.

20. Pasaribu S, Lubis CP. Infestasi cacing usus di bangsal anak
RS.Dr.Pirngadi Medan. MKN 1990;3:195-8.

21. Pasaribu S. Hasil pengobatan oxantel - pirantel pamoat dosis tunggal pada helminthiasis yang ditransmisikan lewat tanah. Maj Kedok Indon 1992;42:679-82.

22. Onadeko MO, Ladipo OA. Intestinal parasitic infestation in rural communities: a focus for primary health care in Nigeria. Afr J Med Med Sci 1989; 18:289-94.

23. Hayimi M, Sumarti, Hasyimi R. Hubungan malnutrisi dan infeksi kecacingan pada anak sekolah dasar di daerah (IDT) Sriamur Bekasi. JEN 1996;2:35-40.

24. Legesse M, Erko B, Medhin G. Efficacy of albendazole and mebendazole in the treatment of Ascariasis and Trichuriasis infection. Ethiop Med J 2002; 40:335-43.

25. Jongsuksuntigul P, Jeradit C, Pornpattanakul S, Chanasari U. A comparative study on the efficacy of albendazole and mebendazole in the treatment of Ascariasis, Hookworm infection and Trichuriasis. Southeast Asian J Trop Med Public Health 1993;4:724-9.

26. Purnomo, Pasaribu MP, Partono F. A comparative study of pyrantel pamoate and a combination of mebendazole and pyrantel pamoate in the treatment of soil transmitted helminths in a rural area, Indonesia. Southeast Asian J Trop Med Pub Health 1981;12:236-41.

27. Lubis CP. Pengobatan helminthiasis pengalaman klinis di laboratorium Ilmu Kesehatan Anak FK-USU. Proceedings of the One Day Simposium "Anthelmintik generasi baru"; 1989; Medan.

28. Sorensen E, Ismail M, Amarasinghe DK, Hettiarachchi I. The efficacy of three anthelminthic drugs given in a single dose. Ceylon Med J 1996;41:42-5.

29. Kan SP, Chua SC. The efficacy of single doses of mebendazole plus levamisole in the treatment of Trichuris trichiura and Ascaris lumbricoides infection. Presented at the $7^{\text {th }}$ APCO Parasitologists' Meeting; 1985; Tokyo. 